\title{
THE STELA OF NES-HOR FROM AKHMIM CG 22142
}

\author{
Ali ABDELHALIM \\ Faculty of Arts, Ain Shams University, Egypt \\ E.mail: ali.abdelhalim@art.asu.edu.eg
}

\begin{abstract}
The aim of this article is to publish and study the stela of Nes-Hor, found at Akhmim and currently stored in the Egyptian Museum Cairo. It contains an important version of the solar hymn BD 15. The columns of texts are arranged in a unique way. In addition to translation and textual analysis, the present study provides a commentary on the content, palaeography and philology of the texts. A genealogical notice will contribute to the understanding of the community of Akhmim during the Greco-Roman Period.
\end{abstract}

يهدف هذ المقال إلي نشر ودر اسة لوحة "نسحور" التي عثر عليها في أخميم وهي الآن في

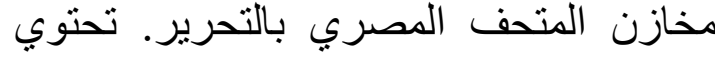
هذه اللوحة علي نسخة هامة من الفصل 10

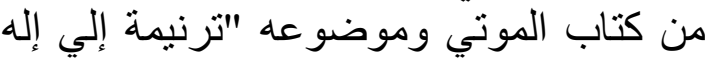

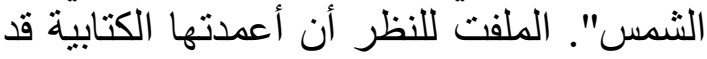
رتبت بطريقة فريدة. تقدم هذه الدراسة نشرا لهذه اللوحة بتضمن قراءة وترة وترهمة وتحليلا

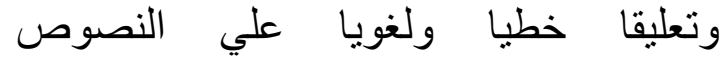
الهيروغليفية, فضلا عن محاولة لفهم شجرة عائلة صاحب هذه اللوحة.

\section{KEYWORDS}

Book of Dead 15, Hawawish, Gods, Solar disk, barque, titles, genealogy, Pasenejdemibnash.
كتاب الموتى فصل 10، الحواويش، الآلهة، قرص الثمس، مركب الثمس، ألقاب، علم الأنساب، باسنجم-ايب-نعش. الأنة

\section{INTRODUCTION}

MASPERO (1885) revealed a large amount of monuments at Akhmim 'Hawawish-cemetery A' including several stelae. ${ }^{1}$ Those stelae date back to the Late and Greco-Roman Periods in Egypt. Most of them are stored in the Egyptian Museum Cairo, and their hieroglyphic texts have been transcribed by A. KAMAL in his Catalogue Général.

Despite its epigraphic importance, this publication of KAMAL contains many transcription mistakes with regards to the hieroglyphs. Those errors may have misled researchers in their translations and consequently in understanding Egyptian funeral thoughts in the Late and

\footnotetext{
${ }^{1}$ Kamal, A., Stèles, II-III; KuHLmanN, Materialien zur Archäologie, 52; 54; 57 n. 283; Bouriant, U., Rapport au Ministre, 369; 381.
}

- 19 - SHEDET Issue nu. 6 (2019), pp. 19-35 
Greco-Roman Periods. A case for such mistakes is the stela of Nes-Hor ${ }^{1}$ son of Pasenejdemibnash and Tjehenet, ${ }^{2}$ Therefore, by reproducing this stela, the author presents a new edition of the text and vignette. Corrigenda for the mistakes of Kamal are included in the footnotes.

\section{DESCRIPTION OF THE STELA (Fig. I):}

This stela of Nes-Hor is made from limestone and measures $58 \times 35 \mathrm{~cm}$. Despite some parts having been left blank and showing the original stone, this stela has fine relief scenes and hieroglyphic inscriptions. It is divided in three parts: a lunette, a horizontal register and a vertical rectangle containing the main hieroglyphic text of 17 columns.

\section{The lunette (Fig. II):}

The lunette is decorated with the popular winged sun-disk and a cobra hanging from each of its sides. Below, two jackals are depicted facing each other symmetrically with a flail over their back. Their tails are represented in a long horizontal position nearly reaching the feathers of the winged sun-disk. The lunette has three phrases as follows:

Top right: 1 a

Top left: fob $=\mathrm{i} \sim \mathrm{n}>\mathrm{pw}$ nb $t \mathrm{~A}-\mathrm{Dsr}: \mathrm{A}<\mathrm{n}>$ ubis, lord of the sacred land (i.e. necropolis).

Below: $=\otimes$ bHdty nTr aA nb $<$ pt $>^{4}$ : Behdite, the great god, lord of the $<$ sky $>$.

\section{THE REGISTER (Fig. II):}

The register contains two semi-balanced vignettes, each of which is accompanied by a text of adoration. They are complementary too. In both vignettes, the deceased stands adoring Re-Harakhte ${ }^{5}$ and the sun-disk with the crew on the solar barque.

The hawk-headed Re-Harakhte is enthroned on the right-hand side. He has the sun-disk and the cobra on his head, while he holds the wAs- scepter in his right hand and the anx-sign in his left hand. No offering table is provided. The following columns run from right to left:

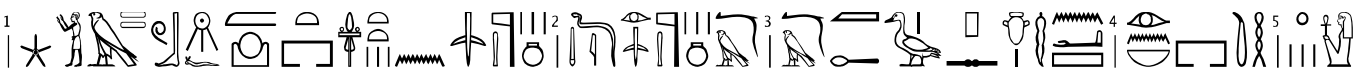

\footnotetext{
${ }^{1}$ Kamal, A., Stèles, p. 124-6. 'Nes-Hor' is a very common name during the Persian (H. de Meulenaere., Apries, in : LÄ I 359) and Greco-Roman periods in Egypt with the meaning of 'He-Who-Belongs-To-Horus' Cf. H. de Meulenaere., Le surnom egyptien, 14; Ranke., PN I, p. 178. Other persons held this name from Akhmim e.g. CG 22023; 22025; 22141, from Abydos CG 22022; 22031 and from other places. Two women bore this name too in CG 22027 (Akhmim) and CG 22131 (Abydos).

${ }^{2}$ For Pasenedjemibnash see Abdelhalim, A., Der Sarkophagdeckel des Pasenedjemibnash, 91f. Thehen(et) 'The-Dazzling-One' as a personal name for both male and female, Ranke., PN, I, 293; Mendel, D., Die Monatsgöttinnen in Tempeln und im privaten Kult, Rites égyptiens 11, Bruxelles, (2005), 49-50.

${ }^{3}$ Although Kamal transcribes n-sign here, it is missing from the name of Anubis in both cases of the lunette.

${ }^{4}$ The word 'sky' does not exist here. However, it is transcribed by Kamal. It arises in the register under the elbow of Nes-Hor facing Re-Harakhte.

${ }^{5} \mathrm{Cf}$. J. Quaegebeur., stèle ptolémaique d'Akhmim, 44 with n. 4. The name Re-Harakhte is written clearly on some stelae, e.g. BM 21636 and Cairo JE 21970: Munro., Spätägyptischen Totenstelen, Abb. 88 and 104.
} 


\begin{tabular}{|c|c|c|}
\hline 1 & $\begin{array}{l}\text { dwA ra-Hr-Axty } \\
\text { wb }<\text { n }>^{1} \text {.f m Axt iAbtt } \\
<i>n \text { smAty Hm-nTr } \\
\text { xmt-nw }\end{array}$ & $\begin{array}{l}\text { Adoring Re-Harakhte as he rises from the } \\
\text { eastern horizon through the stolist and } 3^{\text {rd }} \text { priest }\end{array}$ \\
\hline 2 & $\begin{array}{l}\text { Dd-mdw } i<n><w s>i r^{2} \\
\text { smAty Hm-nTr xmt-nw } \\
\text { ns-Hr }\end{array}$ & $\begin{array}{l}\text { Words to be said by }<\text { Os }>\text { iris, stolist and } 3^{\text {rd }} \\
\text { priest Nes-Hor, }\end{array}$ \\
\hline 3 & $\begin{array}{l}\text { mAa-xrw sA pA-snDm- } \\
\text { ib-nas }{ }^{3}\end{array}$ & true of voice ${ }^{4}$, son of Pasenedjemibnash \\
\hline 4 & $\begin{array}{l}\text { iry.n nb(t) } \mathrm{pr}^{5} \\
\mathrm{THn}<\mathrm{t}>\end{array}$ & born by the mistress of the house Tjhenet. \\
\hline
\end{tabular}

On the left side of the register, the deceased stands adoring in front of the crew of the papyrus solar barque. It rests upon a water surface and contains a solar disk in the middle and three standing deities with their arms downward. Those three deities are Isis, Thoth and Horus. None of their names are recorded. Isis is depicted with her symbol on her head. The Ibis-headed Thoth is remarkable, as his arms are drawn as a single fine line. The falconheaded Horus stands on the stern without rudder. The solar god ( $\mathrm{Re}$ in this case) is addressed to with the following phrases running from left to right:

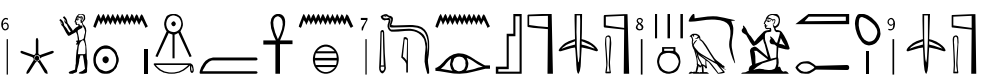

\begin{tabular}{|l|l|l|}
\hline 6 & dwA $n$ ra wbn.k m anx & Adoration to Re, when you rise in life. \\
\hline 7 & $\begin{array}{l}\text { Dd-mdw in wsir smAty } \\
\text { Hm-nTr }\end{array}$ & Recitation by Osiris, stolist ${ }^{6}$ and \\
\hline 8 & xmt-nw ns-Hr mAa-xrw sA & $3^{\text {rd }}$ priest Nes-Hor, true $^{\text {of }}$ voice, son \\
\hline 9 & $\begin{array}{l}\text { smAty Hm-nTr <pA-snDm- } \\
\text { ib-naS> }\end{array}$ & of the stolist and priest, Pasenedjemibnash ${ }^{7}$. \\
\hline
\end{tabular}

\section{THE MAIN TEXT (Fig. II):}

\footnotetext{
${ }^{1}$ The $\mathrm{n}$-sign lacks in the verb 'wbn', while the b-sign in the same verb on a stela published by Quaegebeur, J., stèle ptolémaique d'Akhmim, p. 45.

${ }^{2} \mathrm{~A}$ rare epigraphic writing for 'Osiris' is seen here, with only the eye, omitting the usual st-sign (throne), without parallel.

${ }^{3}$ The original text shows naS as uniliteral signs instead of nxt- and mAa-signs in Kamal's copy. On the other hand, the absence of mAa-xrw after the names of his father or his mother is noteworthy. There is also an exchange between nDm-sign behind ib-sign in Pasenedjemibnash. This exchange arises again in col. 3 of the main text. Note also the move of the determinative of Nes-Hor after mAa-xrw .

${ }^{4}$ 'Nes-Hor' arises again in the same line before mAa-xrw in Kamal's copy.

${ }^{5}$ Kamal's copy retrenches the pr-sign (Sign List O1).

${ }^{6}$ Comments on stolist in Abdelhalim, A., Lunette stelae, 2 n. 10.

${ }^{7}$ A visual design occurred here. The name of the father is written once, but is placed between the two inscriptions; it is to be understood twice.
}

- 21 - DOI: $10.36816 /$ shedet.006.02 
The main text of the rectangle consists of 17 long columns, which are unusually arranged in three sections ${ }^{1}$. Hieroglyphic signs are looking to the right from column 1 to the upper half of column 9 as well as from column 13 to column 17. The lower half of column 9 to column 12 have signs looking left. Since the text is oriented according to the images in register and there is interplay between the texts in both register and main text, this main text and consequently the translation could be read in three sections as follows:

$1^{\text {st }}$ section (A) from column 1 to the middle of column 9 right - left.

$2^{\text {nd }}$ section (B) from column 12 to column 9 left - right.

$3^{\text {rd }}$ section (C) from column 13 to column 17 right - left.

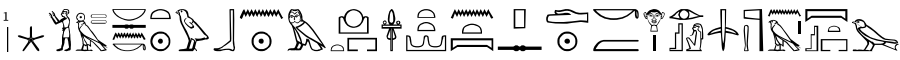

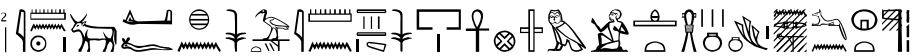

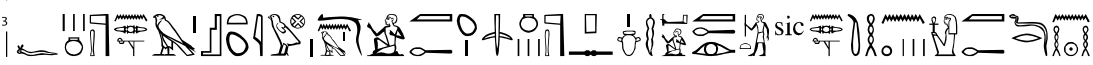

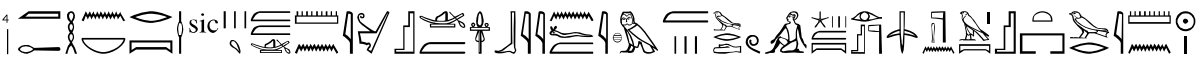

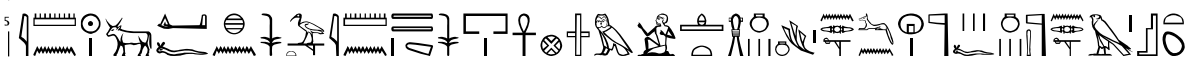

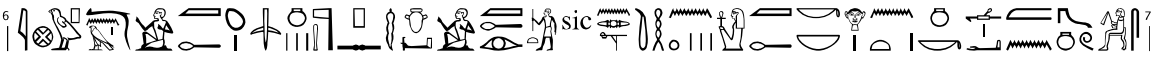

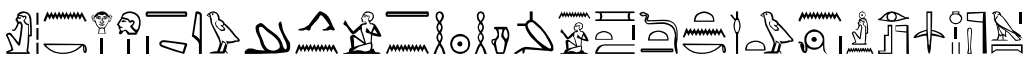

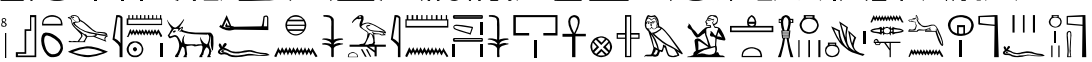

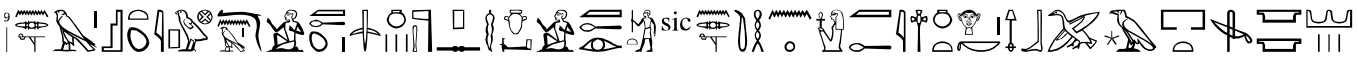

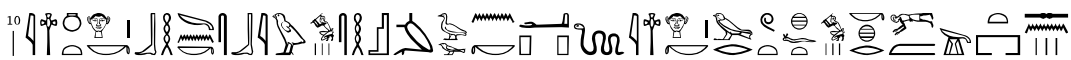

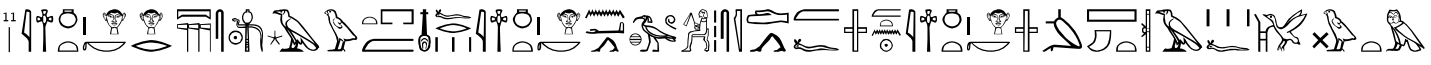

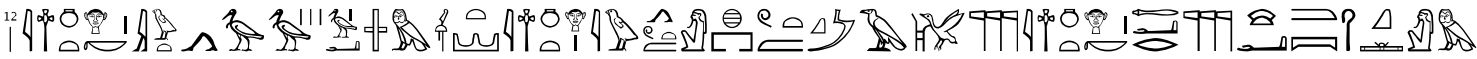

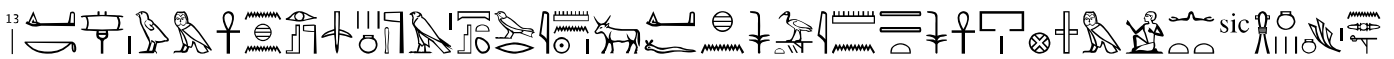

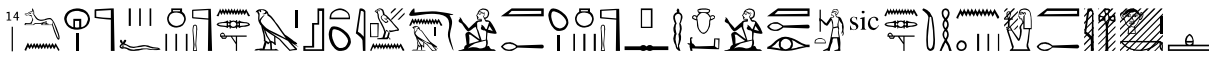

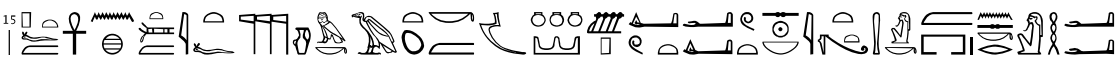

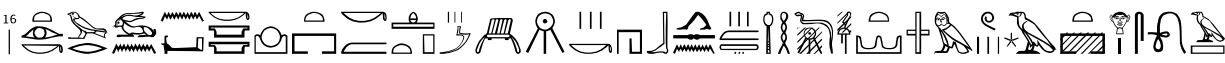

17

\begin{tabular}{|c|c|l|l|}
\hline Sec. & Col. & \multicolumn{1}{|c|}{ Transliteration } & \multicolumn{1}{c|}{ Translation } \\
\hline \multirow{4}{*}{1} & & $\begin{array}{l}\text { dwA ra-Hr-Axty nb } \\
\text { stwt }{ }^{2} \text { wbn m Axt } \\
\text { iAbtt nt pt psD. } \mathrm{km} \\
\mathrm{Hr} \text { wsir smAty Hm- } \\
\mathrm{nTr} \mathrm{n} \mathrm{Hr} \mathrm{Hry-st-} \\
\mathrm{wr}(\mathrm{t})\end{array}$ & $\begin{array}{l}\text { Adoring Re-Harakhte, lord of rays, who } \\
\text { rises in the eastern horizon of the sky. May } \\
\text { you (Re-Harakhte) shine on the face of } \\
\text { Osiris, stolist, priest of Horus who-is-on- } \\
\text { the-great-throne, }\end{array}$ \\
\hline
\end{tabular}

${ }^{1}$ Only two directions of columns in CG 22070; 22143 and 22145.

${ }^{2}$ The determinative is different in Kamal's copy. He transcribes a sunshine (Sign list N8). Despite the word's obvious reading as $s n k$, it is better to read it stwt according to its meaning following Quaegebeur, J., (stèle ptolémaique d'Akhmim, 46, b). There could be a mistake due to similarities between both words in Hieratic. 


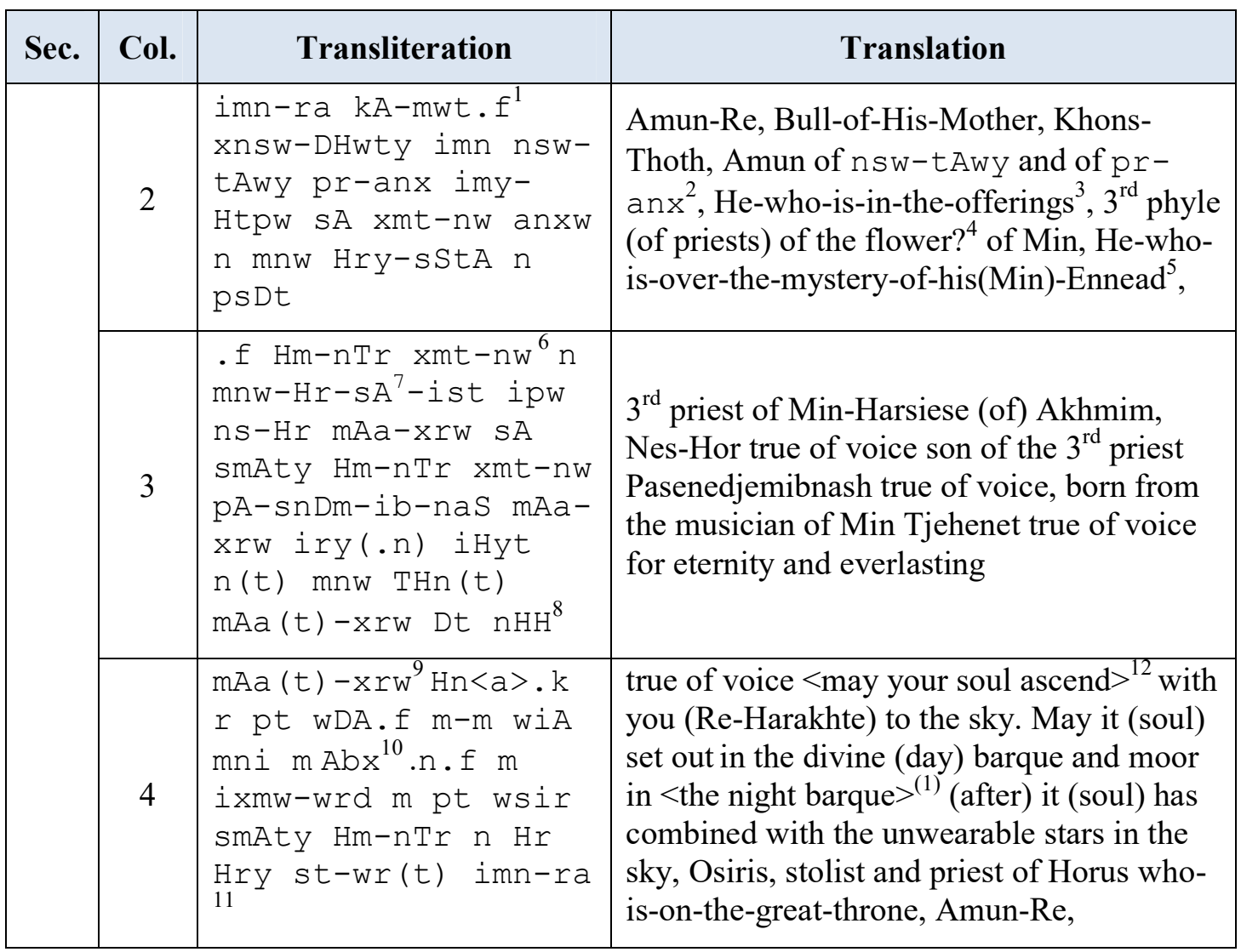

${ }^{1}$ Kamal's copy has the bowl (nw-jar) on the hand (Sign List D39) instead of loaf (D37).

${ }^{2}$ Both nsw-tAwy and pr-anx are in questionable places. According to LEITZ 2002 I, 319, this stela is the sole citation for those epithets of Amun. pr-anx is suggested to be north to Akhmim with a temple for Sobek-Re according to KURTH, Per-anch, in: $L \ddot{A}$ IV, 929 depending on Gardiner, A., $A E O$ II, Nr. 359, 48*f; Montet, P., DG II, 112. In my opinion, both nsw-tAwy and pr-anx are associated with Hermopolis.

3 imy-Htpw is a very rare title. It has no parallel in other stelae from the same period as far as the author knows. Gauthier $(1931,88)$ describes it as 'obscure' as well. He understands it within the other titles in the present stela i.e. imy-Htpw-sA-xmt-anxw-n-mnw. For him, it might refer to the service of flower offerings (as bouquet) for Min. Among those flowers and plants, abw (Lactuca sativa) is well known. Without referring to CG 22142, Leitz ( $L G G$ I, 247) translates imy-Htpw as 'who-is-in-peace' in reference to Re (sungod).

${ }^{4}$ Reading as anxw and translation after Gauthier, H., Personnel du dieu Min, 88; Valeurs phon. II, OrMontp, 1990, 400. The meaning is still obscure.

${ }^{5}$ Unlike Gauthier, H., Personnel du dieu Min, 88, who reads and translates sAb?-n-psDtyw. f 'judge of his ennead'. 'He-who-is-over-the-mystery-of-his-ennead' shows a priestly title mainly associated with mummification. The jackal on the chapel confirms that role. See also Leitz., $L G G$ V, 380f; Koenig, Y., Tai.di-Imen, 261; 273f (note kk); Morenz, L., Die Zauberflöte, p. 86, note 1. For the title in the late NewKingdom see Stanley, Z., The Title hry-sšt 3 to the End of the New Kingdom, in: JARCE 45 (2009/2010), 319-348.

${ }^{6}$ The word ' 3 rd, precedes 'priest', despite ordinal numbers normally following their nouns.

${ }^{7}$ Note the stroke instead of the egg for the word 'son' in all cases. For Min-Harsiese Leitz, LGG III, 294.

${ }^{8}$ Due to their similarity in Hieratic, r-sign has been transcribed instead of t-sign for Dt.

${ }^{9}$ Kamal transcribes $\mathrm{m}-\mathrm{m}$ instead of $\mathrm{mAa}-\mathrm{xrw}$. The last reading ( $\mathrm{mAa}-\mathrm{xrw}$ ) is well attested in other parallels e.g. CG 22052, 22070, 22148. The name before $\mathrm{mAa}-\mathrm{xrw}$ is omitted in our case. It arises again in col. 6.

${ }^{10}$ Reading according to CG 22070, 22145, 22148 and others.

${ }^{11}$ In this column, Amun-Re is superfluous. It is written again in the next column followed by his usual epithet 'Bull-of-His-Mother', which is repeated in all the occurrences of this stela.

${ }^{12}$ After parallels e.g. CG 22052, 5-6; 22114, 12; 22134, 4; 22034, 8-9. manDt -barque added in 22034. 


\begin{tabular}{|c|c|c|c|}
\hline $\mathrm{Se}$ & Col. & Transliteration & Translation \\
\hline & 5 & $\begin{array}{l}\text { imn-ra kA-mwt.f } \\
\text { xnsw-DHwty imn nsw- } \\
\text { tAwy pr-anx imy- } \\
\text { Htpw sA xmt-nw anxw } \\
\text { n mnw Hry-sSt-n- } \\
\text { psDt.f Hm-nTr xmt- } \\
\text { nw n mnw-Hr-sA-ist }\end{array}$ & $\begin{array}{l}\text { Amun-Re, Bull-of-His-Mother, Khons- } \\
\text { Thoth, Amun of nsw-tAwy and of pr- } \\
\text { anx, He-who-is-in-the-offerings, } 3^{\text {rd }} \text { phyle } \\
\text { of the flower for Min, He-who-is-over-the- } \\
\text { mystery-of-his-ennead, the } 3^{\text {rd }} \text { priest of Min- } \\
\text { Harsiese (of) }\end{array}$ \\
\hline & 6 & $\begin{array}{l}\text { ipw ns-Hr mAa-xrw } \\
\text { sA smAty Hm-nTr } \\
\text { xmt-nw pA-snDm-ib- } \\
\text { naS mAa-xrw iry.n } \\
\text { iHyt nt mnw THn(t) } \\
\text { mAa<t>-xrw (in)k nb } \\
\text { Hr-ntt ink wa m nw } \\
\text { spsw }\end{array}$ & $\begin{array}{l}\text { Akhmim, Nes-Hor true of voice, son of } \\
\text { stolist, } 3^{\text {rd }} \text { priest Pasenedjemibnash true of } \\
\text { voice, born from the musician of Min, } \\
\text { Tjehenet true of voice. I am a lord (of } \\
\text { favour) }{ }^{2} \text {, because I am one of (those) who } \\
\text { were pleasing }\end{array}$ \\
\hline & 7 & $\begin{array}{l}\text { ntyw Hr tp tA iw } \\
\text { pH.n.i tA nHH } \\
\text { xnm.n.i mrt m Dt } \\
\text { ntk }{ }^{3} \text { w w (.i) n ra } \\
\text { wsir smAty Hm-nTr } \\
\text { xmt-nw Hr Hry- }\end{array}$ & $\begin{array}{l}\text { on earth. I have reached the land of eternity. } \\
\text { I joined the canal in the everlasting, for it is } \\
\text { you who allotted me to Re. Osiris stolist and } \\
3^{\text {rd }} \text { priest of Horus, who-is-on- }\end{array}$ \\
\hline & 8 & $\begin{array}{l}\text { st-wr(t) imn-ra kA- } \\
\text { mwt.f xnsw-DHwty } \\
\text { imn nsw-tAwy pr-anx } \\
\text { imy-Htpw sA xmt-nw } \\
\text { anxw n mnw Hry-sStA } \\
\text { n psDt.f Hm-nTr } \\
\text { xmt-nw }\end{array}$ & $\begin{array}{l}\text { the-great-throne, Amun-Re, Bull-of-His- } \\
\text { Mother, Khons-Thoth, Amun of nsw- } \\
\text { tAwy and of pr-anx, He-who-is-in-the- } \\
\text { offerings, } 3^{\text {rd }} \text { phyle (of priests) of the flower } \\
\text { for Min, He-who-is-over-the-mystery-of- } \\
\text { his-ennead, } 3^{\text {rd }} \text { priest }\end{array}$ \\
\hline & $9 / 1$ & $\begin{array}{l}\mathrm{n} \text { mnw-Hr-sA-ist ipw } \\
\mathrm{ns}-\mathrm{Hr} \text { mAa-xrw sA } \\
\text { Hm-nTr 3-nw pA- } \\
\text { snDm-ib-naS mAa-xrw } \\
\text { iry (.n) iHyt } \mathrm{n}(\mathrm{t}) \\
\text { mnw THn (t) }{ }^{4} \mathrm{mAa}-\mathrm{xrw}\end{array}$ & $\begin{array}{l}\text { of Min-Harsiese (of) Akhmim, Nes-Hor, } \\
\text { true of voice, son of the } 3^{\text {rd }} \text { priest, } \\
\text { Pasenedjemibnash, true of voice, born from } \\
\text { the musician of Min, Tjehenet, true of } \\
\text { voice. }\end{array}$ \\
\hline B & 12 & $\begin{array}{l}\text { ind Hr.k ii.ti bA } \\
\text { bAw bA Dsr imy imnt } \\
5 \text { ind } \operatorname{Hr}(. \mathrm{k}) \text { ii.ti m } \\
\text { itm }{ }^{6} \text { pr.ti }{ }^{7} \mathrm{mmA}^{8}\end{array}$ & $\begin{array}{l}\text { Hail to you }{ }^{1} \text {, having come as Ba-soul (lord } \\
\text { of) souls }{ }^{2} \text {, sacred Ba-soul who is in the } \\
\text { west. Hail to (you) having come as Atum, } \\
\text { having become }{ }^{3} \text { as creator of the gods. Hail }\end{array}$ \\
\hline
\end{tabular}

${ }^{1}$ cf. CG 22052, 22057, 22148, 22034.

${ }^{2}$ Based on Allen, Th., Book of the Dead, $12 \mathrm{f}$.

${ }^{3}$ Miswritten Independent pronoun. $\mathrm{n}$ - and $\mathrm{t}$-signs replacing each other.

${ }^{4}$ Plural in Kamal's copy.

${ }^{5}$ Double t-signs in Kamal's copy.

${ }^{6}$ cf. CG 22146. 1; 22148. 6-7; 22185. 5-6.

${ }^{7}$ Kamal transcribes t-sign instead of the $x$-sign.

${ }^{8}$ Kamal confused between t-sign and q-sign due to similarity. 


\begin{tabular}{|c|c|c|c|}
\hline Sec. & Col. & Transliteration & Translation \\
\hline & & $\begin{array}{l}\text { nTrw ind } \operatorname{Hr} . k \text { aA } r \\
n \operatorname{Rrw} \text { xa } m \text { pt HqA } m\end{array}$ & $\begin{array}{l}\text { to you, Greater than gods, who rises in the } \\
\text { sky, ruler in }<\text { the netherworld }>^{4} \text {. }\end{array}$ \\
\hline & 11 & $\begin{array}{l}\text { ind Hr.k Hry nTrw } \\
\text { sHD dwAt m nfrw (.f) } \\
\text { ind Hr.k nai(w) Axw } \\
\text { Spsw sqd.f imy itn } \\
\text { ind Hr.k imy StAw.f } \\
{ }^{6} \text { gmA dwAt }{ }^{7} \mathrm{~m}\end{array}$ & $\begin{array}{l}\text { Hail to you chief of gods, who illuminates } \\
\text { the netherworld by (his) beauty }{ }^{8} \text {. Hail to } \\
\text { you, who conveys the notable spirits, when } \\
\text { he rows within (his) disk }{ }^{9} \text {. Hail to you who } \\
\text { is in his concealment, creator of the } \\
\text { netherworld by }<\text { his sun light }>^{10} \text {. }\end{array}$ \\
\hline & 10 & $\begin{array}{lrrr}\text { ind } & \text { Hr.k } & \text { bHn.k } & 11 \\
\text { sbyw } & \text { stm.n.k aApp } \\
\text { ind Hr.k } & 12 \text { wr } & \text { tw } \\
\text { xftyw.k } & \text { xr(.w) } & m \\
\text { nmt.sn } & & \end{array}$ & $\begin{array}{l}\text { Hail to you! You will slain the rebels, after } \\
\text { you perished Apophis. Hail to you! You are } \\
\text { great, while your enemies have fallen into } \\
\text { their slaughter }{ }^{13} \text {. }\end{array}$ \\
\hline & $9 / 2$ & $\begin{array}{l}\text { ind } \operatorname{Hr.k} \text { wbA } \operatorname{dwAt}^{14} \\
\text { s.Smw awy smyt }\end{array}$ & $\begin{array}{l}\text { Hail to you, opener of netherworld }{ }^{15} \text { and } \\
\text { governor of the double doors of necropolis. }\end{array}$ \\
\hline $\mathbf{C}$ & 13 & $\begin{array}{l}\text { di.k } \text { Taw }^{16} \text { m anx } n \\
\text { wsir smAty Hm-nTr } \\
\text { xmt-nw Hr Hry st- } \\
\text { wrt imn-ra } \text { kA-mwt }^{17} \\
\text {.f xnsw-DHwty imn } \\
\text { nsw-tAwy } \\
\text { imy-Htpw }{ }^{18} \text { sA } \text { xmt-nw } \\
{ }^{19} \text { anxw n mnw }\end{array}$ & $\begin{array}{l}\text { May you give }<\text { refreshing }>\text { breath of life to } \\
\text { Osiris, stolist and priest of Horus who-is- } \\
\text { on-the-great-throne, Amun-Re, Bull-of-His- } \\
\text { Mother, Khons-Thoth, Amun of nsw- } \\
\text { tAwy and of pr-anx, He-who-is-in-the- } \\
\text { offerings, } 3^{\text {rd }} \text { phyle of (of priest) of the } \\
\text { flower for Min }\end{array}$ \\
\hline
\end{tabular}

${ }^{1}$ Jansen-Winkeln, K., Text und Sprache der 3. Zwischenzeit, $180 \mathrm{ff}$.

${ }^{2}$ Against Allen: Ram of Rams (Book of the Dead, 14g; 23g; ) or Blessed one, master of Souls (p. 24g).

${ }^{3}$ An allusion to transformations of the solar-god. See Atum in the general commentary below.

${ }^{4}$ cf. CG 22148. 8; 22185. 8; 22071. 6.

${ }^{5}$ The m-sign is a confusion with the ship-sign, the determinative to the verb (sqd) in Wb IV, 308, 7.

${ }^{6}$ A sign for goose in Kamal's copy instead of 3-sign.

${ }^{7}$ The two sticks crossed (four arms) could be a miswriting of the star for dwAt (five arms), which occurred at the beginning of the same column.

8 'nfrw' means also rays cf. CG 22052; Wb II, 262, 2. Elsewhere, other parallels have iAxw (CG 22071, 3).

${ }^{9}$ This phrase corresponds the depiction of the sun-god as a solar-disk in his barque in the register.

${ }^{10}$ After 22071. 9 from Thebes.

${ }^{11}$ Kamal transcribes nb instead of $\mathrm{k}$.

12 Kamal's copy has $\stackrel{\text { 是. }}{12}$

${ }^{13}$ For Apophis see Fortier, A., Le voyage de Rê, 276-283; Régen, I., Quand Isis met à mort Apophis, 247271; Quack, J., Apopis, Nabelschnur des Re, 377-379, Morenz, L., Apophis, 201-205; Kousoulis, P., The function of $h k 3,362-371$.

${ }^{14}$ Kamal transcribes incorrectly the t-sign above the pr-sign.

${ }^{15}$ An epithet for gods and deceased. Leitz, LGG II, 299; Assmann, J., Liturgische Lieder, $81 \mathrm{f}$.

${ }^{16}$ Kamal transcribes a flesh and vulture.

${ }^{17}$ Kamal transcribes again the nw-jar on the hand and tAwy-instead of $t$-sign.

${ }^{18}$ Instead of Htp-sign, there is $\Omega$ in the original text as miswriting for the Htp-sign due to their similarity in the Hieratic mother copy.

${ }^{19}$ Note the nw-jar before the plural in the ordinal $3^{\text {rd }}$ in all cases of the stela. 


\begin{tabular}{|c|c|c|c|}
\hline Sec. & Col. & Transliteration & Translation \\
\hline & 14 & $\begin{array}{l}\text { Hry-sStA n psDt.f } \\
\text { Hm-nTr xmt-nw } n \\
\text { mnw-H-sA-ist ipw } \\
\text { ns-Hr mAa-xrw sA } \\
\text { Hm-nTr xmt-nw pA- } \\
\text { snDm-ib-naS mAa-xrw } \\
\text { iry (.n) iHyt n(t) } \\
\text { mnw THn(t) }{ }^{2} \text { mAa (t)- } \\
\text { xrw ind Hr.k }\end{array}$ & $\begin{array}{l}\text { He-who-is-over-the-mystery-of-his-ennead. } \\
3^{\text {rd }} \text { priest of Min-Harsiese }<\text { in }>\text { Akhmim, } \\
\text { Nes-Hor true of voice, son of } 3^{\text {rd }} \text { priest } \\
\text { Pasenedjemibnash, true of voice born (by) } \\
\text { musician of Min, Tjehenet true of voice. } \\
\text { Hail to you, }\end{array}$ \\
\hline & 15 & $\begin{array}{l}\text { Htp. }{ }^{4} \mathrm{~m} \text { anx itm it } \\
\text { nTrw } x \mathrm{~nm} \cdot \mathrm{k} \text { mwt.k } \mathrm{m} \\
\mathrm{mAnw} \text { Ssp tw awy.s }{ }^{5} \\
\text { ra-nb tit Hm.k m- } \\
\text { Xnw }^{6} \mathrm{skr} \text { Haa }\end{array}$ & $\begin{array}{l}\text { who sets in life (as) Atum, father of gods, } \\
\text { when you join your mother (Nut) in the } \\
\text { western mountain }{ }^{7} \text {. May her arms receive } \\
\text { you every day. May the form of your } \\
\text { majesty be inside Sokar, while you rejoice } \\
\text { (over) }\end{array}$ \\
\hline & 16 & 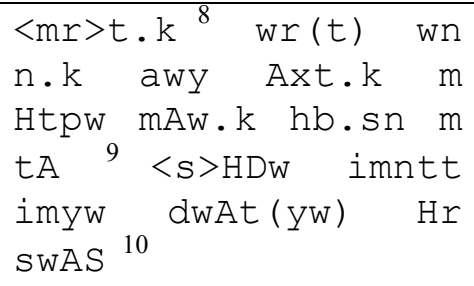 & $\begin{array}{l}\text { your great eye. May the double doors of } \\
\text { your horizon be opened for you in peace. } \\
\text { May your rays enter into the land } \\
\text { illuminating the west, while the dwellers of } \\
\text { the netherworld intone, acclaim and }\end{array}$ \\
\hline & 17 & $\begin{array}{l}\text { nHt mAA.k ra-nb Htp } \\
\text { nTrw m tA Smsw.k Hr } \\
\text { wnn m-xt.k bA.k } \\
(\mathrm{Hr}) \text { mdt }<\ldots>^{11}\end{array}$ & $\begin{array}{l}\text { beg to see you every day. (May you let) } \\
\text { gods set in earth, while your followers are } \\
\text { behind you and your bA-soul speaks }<\text { to } \\
\text { you }>\text {. }\end{array}$ \\
\hline
\end{tabular}

\section{GENERAL COMMENTARY}

According to Munro (1973, 132, n. 2), the stela of Nes-Hor has been classified as 'Akhmim Group II C', which dates it between the $29^{\text {th }}$ Dynasty and Ptolemy IV. More accurately, it could be dated to the beginning of the $2^{\text {nd }}$ century BCE. According to Buhl ${ }^{12}$, the father of

\footnotetext{
${ }^{1}$ The title smaty is omitted here.

${ }^{2}$ Kamal transcribes a seated woman without an anx-sign on her knee.

${ }^{3} \mathrm{Kamal}$ inserts nw and t-signs, which do not exist in the original.

${ }^{4}$ Note $\mathrm{p}$-sign before $t$-sign. The use of $3^{\text {rd }}$ instead of $2^{\text {nd }}$ person is inscrutable.

${ }^{5}$ The $2^{\text {nd }}$ arm in awy has something on the hand due to a confusion with the determinative of the verb $\mathrm{sSp}$ (arm with strike). Beneath, the t-sign is confused with the two strokes for dualism (cf. CG 22143, 22145).

${ }^{6} \mathrm{nw}$-jar is certain in 22145 and 22148 .

${ }^{7}$ The deceased joins his mother Nut in reference to the west since PT 537, 593, 452, 450.

${ }^{8}$ Cf. CG 22143, 22145, 22148, 22149, 22185. The great (left) eye belongs to Horus in PT 301. It also refers to plants within fields in PT 317.

${ }^{9}$ After CG 22149 and 22145. The latter has 'the two lands'.

${ }^{10}$ Kamal transcribes w instead of A.

${ }^{11}$ Kamal transcribes 3 (? $)$ YIIIIII, which are invisible nowadays.

${ }^{12}$ Buhl, M., Anthropoid Stone Sarcophagi, 213 (E, a 8).
} 
Nes-Hor 'Pasenedjemibnash' lived at the end of the $3^{\text {rd }}$ or beginning of $2^{\text {nd }}$ century BCE. Other stylistic criteria of dating could be given here i.e. long garments and the silhouettes in back-to-back position, which are famous for Akhmim at that time.

Both the vignette and the text of this stela present a significant example of the Book of Dead 15, which first appeared at the end of the $18^{\text {th }}$ dynasty in Theban tombs, as one of the hymns to the sun-god ${ }^{1}$. The earliest type of Theban stelae ${ }^{2}$ contained solar hymns but they were addressed to the god Atum instead of the solar barque in the vignette (exx in MuNRO 1973, Abb. 13-28). Then it was transferred exactly to the Edfu stelae (exx. in MunRo 1973, Abb. 78f, 84). The type of Abydos (MunRo 1973, Abb. 108ff) seems to be very abbreviated with a focus on the vignette more than the text.

BD 15 on the Late and Greco-Roman stelae from Akhmim has been developed to be in the following appearance. The register of the Akhmimic style is distinguished with a solar barque containing the sun-disk, Isis, Thoth and Horus. Hieroglyphic texts of Akhmim stelae are inscribed in vertical columns ${ }^{3}$ unlike those from other places, where columns tend to be oriented towards the centre. It is moreover noteworthy, that this stela has neither offering table nor rudder in the barque, nor names for its crew unlike its parallels. Both scenes of the deceased in adoration before Re-Harakhte, represent the standard scenes associated with BD 15a and 15f.

The content of this stela of Nes-Hor could be divided into five main topics:

1- Adoration to the sun-god (register and col. 1).

2- An appeal to the sun-god in his various epithets at rise and set (sec. B and C).

3- Titles of deceased and his parents (in most columns).

4- Wishes for the soul of the deceased (cols. 1, 4, 13, 17).

5- A speech from the deceased stating that he is blessed (col. 6-7).

Both orientation and arrangement of columns are characteristic and unique in the rectangle. They are divided into three sections (A, B and C) ${ }^{4}$ as mentioned above. Orientation and arrangement of columns could be associated with adoration phrases and scenes in the register, where the deceased is depicted twice, i.e. back-to-back. He adores Re-Harakhte on the right hand and the solar barque on the left hand. Section A runs from right to left to correspond to the speech of the deceased to Re-Harakhte, while section B represents the appeal of the deceased addressed to Re, who resides as a solar disk inside the barque. This appeal (inD-Hr) to several forms of sun-god was repeated 9 times, perhaps due to the Heliopolitan ennead.

\footnotetext{
${ }^{1}$ Compare for solar hymns Assmann, J., Liturgische Lieder; ID, Sonnenhymnen; Barguet, Le Livre des Morts; Hornung, Totenbuch, 421f; Allen, Some Egyptian Sun Hymns; ID, Book of the Dead, 26. The latter attested this stela (p. 26, 226; 243) as BD 15B5 with bad translation.

${ }^{2}$ Quaegebeur, J., stèle ptolémaique d'Akhmim, 52.

${ }^{3}$ e.g. CG 22052, 22057, 22070, 22143, 22145, 22146, 22148, 22185.

${ }^{4}$ Other examples have only two sections. Cf. CG 22070, 22143, 22145, 22146.
} 
Unlike other stelae displaying BD 15, the formula inD-Hr does not only occur at the beginning of columns but also throughout. The formula inD-Hr exists however in line 9 as a switch for the direction of writing exactly beneath the prow of the barque and near the feet of the deceased.

While section (A) expresses the adoration of the solar-god during the day, section (C) is concerned by his night-time journey. Therefore, section (C) is located on the left hand, opposite to section (B) beneath the solar-barque to express this idea. This means also that the deceased adores the sun-god at his sunrise by day and his sunset at night.

As seen through this stela, Heliopolitan, Theban and Hermopolitan aspects are very apparent on this version of BD 15. Deities mentioned in both the register and the main text play an important role in the solar hymns, i.e. Re, Re-Harakhte, Atum, Amun-Re and Thoth.

Re-Harakhte is adorned at his rise in the western and eastern horizon of the sky. By rising, he shines on the face of Nes-Hor (col. 1). At his set (i.e. entering into the netherworld), he gives the breath of life to the deceased. In addition, one could associate the right side of the register with the east and the left with the west. This idea is emphasized in the accompanying texts. The deceased adores Re-Harakhte at the eastern horizon on the right. He refers to the west on the left side by the phrase 'you rise in life' ${ }^{1}$.

Atum is mentioned twice, i.e. in cols. 12 and 15, where the deceased transforms into Atum the primeval god at sunset and sunrise in reference to the resurrection of the dead according to the transformation of the sun-god. Atum is described here as Father of gods. He joins Nut in the western mountain. His image is inside Sokar, while he rejoices over the great eye. The relation between Sokar and the great eye in the present text hints at thinking about feasts during the years of Atum ${ }^{2}$. The great eye accentuates also the night aspect of the sun-god (Atum and Sokar) and might refers to the sun-disk inside the barque. On the stela of another Nes-Hor (CG 220141), it is stated that the sun-god 'comes as Re and sets as Atum'.

Amun/-Re has two epithets on this stela. The $1^{\text {st }}$ epithet is Bull-of-His-Mother, while the other epithet is Amun of nsw-tAwy and of pr-anx. According to Leitz, this stela contains the only citation for this last epithet, the $1^{\text {st }}$ half of which may refer to the origin of Amun from the $15^{\text {th }}$ nome in Middle Egypt, i.e. Hermopolis (On). It is therefore no coincidence that Amun occurs eight times in this stela's text ${ }^{3}$. This refers certainly to his relation to the Hermopolitan ogdoad. Moreover, BD 15 is originally from Thebes, the main cult centre of Amun-Re.

\footnotetext{
${ }^{1}$ Cf. Allen, Some Egyptian Sun Hymns, p. 355; Quaegebeur, J., stèle ptolémaique d'Akhmim, p. 44f for the relationship between east and west to the forms of the sun-god. For Re-Harakhte BERTEAUX, Harachte.

${ }^{2}$ Cf. Graindorge-Hereil, Le dieu Sokar, p. 270. Generally for Atum and his roles, forms and relations to other deities, see Myśliwiec, Studien zum Gott Atum.

${ }^{3}$ except for the repetition in col. 5, which is superfluous.
} 
Three deities represent the crew around the solar disk: Isis, Thoth and Horus. They help the sun-god in his journey through the netherworld. They personify his magical, intelligent and royal power.

Through her magic, Isis ${ }^{1}$ protects the sun-god against his enemies especially in the $7^{\text {th }}$ night hour of Amduat ${ }^{2}$. Furthermore, she represents the day-barque of the sun-god in the Pyramid Texts (210a-c).

Thoth represents the intelligence of the sun-god as well as his command, giving orders for the doors of the netherworld to be opened. The existence of Thoth in the solar-barque is evident, since he also punishes all enemies of $\mathrm{Re}^{3}$. This refers certainly to the natural struggle between light of the moon (Thoth) and darkness (enemy of sun-god). As the vizier of the sun-god, Thoth leads the crew of the barque in reference to the stars, as he computes those stars. Furthermore, Thoth is the one who heals the eye of the sun-god, which represents the barque itself $\mathrm{f}^{4}$.

In addition, Thoth and Khons are identified on this stela ${ }^{5}$. This identification points to their lunar character, as the name Khons means 'wanderer' or 'traveller' in reference to the moon in the sky. The filiation of Khons to Amun-Re might be understood in comparison with his relation to Thoth. Both Thoth and Amun come from Hermopolis.

Horus is also depicted in the solar barque. He is generally thought as the pilot-of-the-boat ${ }^{6}$. Although Horus has neither rudder, nor this name in the present example, he holds elsewhere ${ }^{7}$ the rudder of the stern to direct the journey of the sun. In the rectangle (cols. 1, 4 and 13) the deceased served as priest of Horus He-who-is-on-the-Great-Throne.

Sokar is mentioned once in col. 15 of the current stela. A connection exists between him and Atum as well as the great eye as discussed above. Sokar refers here to a place more than a divinity. It corresponds the $4^{\text {th }}$ or $5^{\text {th }}$ hour of the Amduat ${ }^{(8)}$. Then the eye refers to light as an offering ${ }^{9}$, it helps the deceased in resurrecting as illustrated in the Amduat,

\footnotetext{
${ }^{1}$ For the role of Isis in the solar-barque see Münster, M., Untersuchungen zur Göttin Isis, 19f, 90f, 98f.

${ }^{2}$ Hornung, E., Amduat, 123 (nr. 505). Compare also the following epithet of Isis in Dakka temple 'she who destroys Apophis in his moment', Roeder, G., Tempel von Dakke, line Da, 594.

${ }^{3}$ BD 15: Allen, Book of the Dead, 12, section b. In this context, the role of Thoth is equal to that of Seth in the Ramesside period. Seth is also the god of thunder which removes the darkness. For this role see, Boylan 1922, 60 (n. 4); te Velde, Seth, 99-108; Bleeker, Hathor and Thoth, 119-123. Cf. CG 22025, 12. Generally for Thoth see Boylan, P., Thoth the Hermes of Egypt, 58-61; Stadler, M., Weiser und Wesir, 442f.

${ }^{4}$ BD 130: Allen, Book of the Dead, 106.

${ }^{5}$ For Khons-Thoth, see Boylan, P., Thoth the Hermes of Egypt, 204-208; Leitz., LGG V, 771-772; Labrique, Fr., Khonsou et la néoménie à Karnak, 200; 206; Stadler, M., Weiser und Wesir, 442f. Since the Ramesside period, Khons-Thot represents the lunar child. Cerny, J, Egyptian Stelae, ${ }^{\circ} 10$. For the worship of Thoth and his role in Akhmim see Abdelhalim, A., Lunette stela, 14 (with note 19).

${ }^{6}$ Cf. Leitz, $L G G$ V, 948 .

${ }^{7}$ e.g. CG 22052, 22057, 22070, 22102, 22146, 22148.

${ }^{8}$ Hornung 1991, 68-77; Graindorge-Hereil 1994, 352; 370; 467.

${ }^{9}$ The idea of offering is emphasized in PT $\S 2069$ a (Faulkner 1969, 295), where the house of Sokar is attested. A bnbn-loaf exists in this house to prove the idea of offering.
}

- 29 - DOI: $10.36816 /$ shedet.006.02 
where Sokar receives the eye from Thoth ${ }^{1}$. Both of them are lunar gods ${ }^{2}$.

This large amount of deities mentioned with their epithets on the stela refer certainly to the fact that its owner, Nes-Hor, was an important and prominent person at the time. He served as priest for most of the above mentioned deities. Six priestly titles are well attested, repeated four times. Nes-Hor was a stolist (smAty), priest (Hm-nTr) of Horus, He-who-isin-the-offerings (imy-Htpw), $3^{\text {rd }}$ phyle (of priests sA xmt-nw) of the flower for Min and a $3^{\text {rd }}$ priest $(\mathrm{Hm}-\mathrm{nTr} x \mathrm{xt}-\mathrm{nw})$ of Min-Harsiese (of) Akhmim. Another proof to confirm this idea is the recitation phrase $(D d-m d w)$ on the register, which follows the temple system. Both recitation and appeal show a poetic form of this hymn.

\section{Palaeographical, phraseological and philological notes}

The epigraphic evidence shows that conversions occur regularly between signs and sometimes between words. The scribe wrote the $\mathrm{p}$-sign before $t$-sign in many cases especially in the word Htp (cols. 15 and 17). Also in col. 3 the word ' $x m t-n w: 3$ rd, precedes the word 'Hm-nTr: priest' in many cases despite ordinal numbers following nouns. The independent pronoun $n t k$ has the t-sign before the $n$-sign in col. 7 . This could also be considered miswriting, also seen in the word $d_{3} t$ in col. 11 beside other cases.

A confusion sometimes occurs between signs, such as t-sign and $r$-sign (col. 3), S-sign and mn-sign (col. 5), k-sign and nb-sign (col. 10), z-sign and tA-sign apparently due to their similar hieratic appearance. This allows here to assume that a hieratic papyrus had been used to copy from into the stone stelae. The original version has not been found but other papyri coming from Akhmim could support such suggestion ${ }^{3}$.

Some signs and words were omitted in the texts, as seen in multiple instances. The n-sign is missing in $i<n>p w, w b<n>, T h<n t>$ and omitted in bHn (col. 10) due to the dative. The a-sign in $\mathrm{Hn}\langle\mathrm{a}\rangle$ (col.4), the nw-jar in $\langle i n\rangle k$ (col. 6). Some words were completely omitted e.g. the name of deceased before mAa-xrw in col. 4. It appears however again in col. 6. The word smAty is omitted in col. 14. However, some signs and words are superfluous and inscribed twice, e.g. the word Amun-Re (col. 4) and t-sign (awy col. 15).

All those errors ${ }^{4}$, omissions, conversions and confusions between signs are very common in the texts of Akhmim in Late and Greco-Roman Periods.

\section{A Genealogical notice:}

As the stela belongs to Nes-Hor son of Pasenedjemibnash, it is worth here reconstructing

\footnotetext{
${ }^{1}$ Hornung, E., Nachtfahrt der Sonne, 62; Hornung, E., Amduat I, 71 (nr. 306).

${ }^{2}$ Graindorge-Hereil, Le dieu Sokar, 377f.

${ }^{3}$ E.g. Pap. Nes-Min in Clère, J., Le papyrus de Nesmin; Pap. of Hor in Mosher, The Papyrus of Hor; Pap. Berlin 10477 in Lüscher, B., Das Totenbuch pBerlin P. 10477; Pap. Nes-Shu in Küffer, A., Sous la protection de Nout. 3, 10-11, Figs. 11-12. Albert, F., La composition du livre des Morts tardif, 39-46.

${ }^{4}$ cf. Quaegebeur, J., stèle ptolémaique, 45.
} 
the family tree of Nes-Hor from Akhmim:

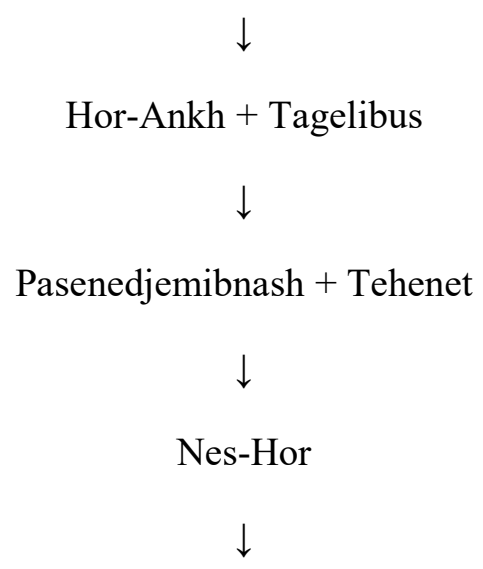

For now, no descendant of Nes-Hor has been identified. This may be due to the popularity of his name, making the next generations very confusing and questionable. Detailed researches on the families of Akhmim are still needed.

\section{CONCLUSIONS}

This study described how the stela of Nes-Hor is unique for its orientation of columns beside other above mentioned characteristics. Both vignette and text are considerable. They show an important version of BD 15a and $15 \mathrm{f}$ that is distinctive for Akhmim. Deities were chosen in order to reinforce the importance of that chapter for the deceased. However, there are many epigraphic errors in the texts on stelae from Akhmim. Although the name NesHor is common in documents of the time, the owner of the stela is assumed to have lived around the beginning of the $2^{\text {nd }}$ century BCE. A wider study would be of interest for the understanding of the on the BD 15 on stelae of the Late and Greco-Roman Periods and the descendants of this Nes-Hor.

\section{ACKNOWLEDGEMENT}

I am grateful to my colleagues in the Cairo Museum for permission to publish this stela and for the photo. 


\section{REFERENCES}

- Abdelhalim A., A Lunette Stela of Pasenedjemibnash in Cairo Museum CG 22151, in: BIFAO 114 (2014), pp. 1-18.

- Abdelhalim, A., Der Sarkophagdeckel des Pasenedjemibnash im Ägyptischen Museum Kairo, in: $A S A E$ 86, (2012/13), pp. 91-124.

- Albert, F., La composition du livre des Morts tardif: des traditions locales aux traditions 'scripturales', in: Egypte Afrique \& Orient (2006), 43, p. 39-46.

- Allen, Th., Some Egyptian Sun Hymns, in: JNES 8 (1949), p. 349-355.

- ..........., The Book of the Dead or Going Forth by Day, SAOC 37, (Chicago 1974).

- Assmann, J., Liturgische Lieder an den Sonnengott: Untersuchungen zur altägyptischen Hymnik, in: MÄS 19, (München 1969).

- .............., Sonnenhymnen in Thebanischen Gräbern (Theben I), Mainz 1983.

- Barguet, P., Le Livre des Morts des Anciens Egyptiens, (Paris 1967).

- Berteaux, V., Harachte: Ikonographie, Ikologie und Einordnung einer komplexen Gottheit bis zum Ende des Neuen Reiches, (Munich 2005).

- Bleeker, J., Hathor and Thoth, two Key Figures of the Ancient Egyptian Religion, Studies in the History of Religion XXVI, (Brill 1973).

- Bouriant, U., 'Rapport au Ministre de l'Instruction Publique sur une Mission dans la Haute-Égypte (1884-1885)', in G. Maspero, MMAF I $\mathrm{I}^{3}$ (Paris, 1887).

- Boylan, P., Thoth the Hermes of Egypt, (Londres 1922).

- Buhl, M., The Late Egyptian Anthropoid Stone Sarcophagi (Copenhagen, 1959).

- Cerny, J., Egyptian Stelae in the Bankes Collection, (Oxford 1958).

- Clère, J., J., Le papyrus de Nesmin. Un Livre des Morts hiéroglyphique de l'époque ptolémaïque, vol. 10: Bibliothèque Générale, (Cairo 1987).

- de Meulenaere, H., Le surnom égyptien à la Basse Epoque, (Leiden 1966).

- Faulkner, R., The Ancient Egyptian Pyramid Texts, (Oxford 1969).

- Fortier, A., Le voyage de Rê et sa lutte contre Apophis, in: A. Quertinmont, (ed.), Dieux, génies et démons en Egypte ancienne: à la rencontre d'Osiris, Anubis, Isis, Hathor, Rê et les autres, (Paris 2016), pp. 276-283.

- Gabolde, L., Un linteau tentyrite de Thoutmosis III dédié à Amon, in: BIFAO 99 (1999), pp. 195-200.

- Gauthier, H., Le Personnel du dieu Min, RAPH 3, 1931.

- Graindorge-Hereil, C., Le dieu Sokar à Thebes au Nouvel Empire, GOF IV 28, 1, (Wiesbaden 1994).

- Helck, W., Untersuchungen zu den Beamtentiteln des Ägyptischen Alten Reiches, $\ddot{A g F o r s c h ~ 18,1954 . ~}$

- Hornung, E., Das Amduat, I, (̈̈gAbh 7, 1963).

- ............, Das Totenbuch der Ägypter, (Munich 1979).

- ............, Die Nachtfahrt der Sonne: Eine Altägyptische Beschreibung des Jenseits, (Munich 1991).

- Jansen-Winkeln, K., Text und Sprache der 3. Zwischenzeit, ÄAT 26 (Wiesbaden 1994).

- Jones, D., An Index of Ancient Egyptian Titles, Epithets and Phrases of the Old Kingdom, BAR, 2000.

- Kamal, A., Stèles ptolémaiques et romaines, tome I, CGC, (Cairo, 1905).

- Koenig, Y., Le contre-envoûtement de Ta-i.di-Imen, in: BIFAO 99 (1999), pp. 259281. 
- Kousoulis, P., The function of $h k 3$ as a mobilized form in a theological environment: the apotropaic "ritual of overthrowing Apophis", in Z. Hawass, and P. Lyla (eds), Egyptology at the dawn of the $21^{\text {st }}$ century: Proceedings of the $8^{\text {th }}$ International Congress of Egyptologists, Cairo 2000, 2 (Cairo 2003), pp. 362-371.

- Küffer, A., Sous la protection de Nout, déesse du ciel. Le trousseau funéraire du prêtre Nes-Shou au Musée d'Yverdon et région, in: archäologie schweiz/archéologie suisse/archeologia svizzera, 29, 3 (2006), 1-13.

- Kuhlmann, K., Materialien zur Archäologie und Geschichte des Raumes von Achmim, SDAIK 11 (Mainz, 1983).

- Labrique, Fr., Khonsou et la néoménie à Karnak, in D. BudDE et alii (éd.) Kindgötter im Ägypten der griechisch-römischen Zeit. Zeugnisse aus Stadt und Templel als Spiegel des interkulturellen Kontakts, OLA 128, (2003), pp. 195-224.

- Lepsius. R., Das Todtenbuch der Ägypter (nach dem hieroglyphischen Papyrus in Turin), (Leipzig 1842).

- Lüscher, B. (ed.), Das Totenbuch pBerlin P. 10477 aus Achmim. (mit Photographien des verwandten pHildesheim 5248): HAT 6, (Wiesbaden 2000).

- D. Mendel., Die Monatsgöttinnen in Tempeln und im privaten Kult, Rites égyptiens 11, (Brussels 2005).

- Montet, P., Etudes sur quelques prêtres et fonctionnaires du Dieu Min, in: JNES 9, (1950), p. 18-27.

- Morenz, L., Apophis: on the origin, name, and nature of an ancient Egyptian antigod, in: JNES 63 (3: 2004), pp. 201-205.

- Morenz, S., Die Zauberflöte: Eine Studie zum Lebenszusammenhang, (Köln 1952).

- Mosher, M., The Papyrus of Hor (BM EA 10479) with Papyrus MacGregor. The Late Period Tradition at Akhmim, Bd. 2: Catalogue of the Books of the Dead in the British Museum, London 2001.

- Munro, Die Spätägyptischen Totenstelen, ÄgForsch. 25, Glückstadt 1973.

- Münster, M., Untersuchungen zur Göttin Isis vom Alten Reich bis zum Ende des Neuen Reiches:vom Alten Reich bis zum Ende des Neuen Reiches. Mit hieroglyphischem Textanhang, MÄS 11 (1968).

- Myśliwiec, K., Studien zum Gott Atum, 2 vols (=HÄB $5 \& 8$ Gerstenberg 1978/1979).

- Quack, J., Apopis, Nabelschnur des Re, in: SAK 34 (2006), pp. 377-379.

- Quaegebeur, J., Une stèle ptolémaique d'Akhmim, in: GM 112 (1989), p. 43ff.

- Quirke, St., Titles and Bureaux of Egypt 1850-1700, GHP Egyptology 1, (2004).

- Ranke, H., Personen Namen I.

- Régen, I., Quand Isis met à mort Apophis: variantes tardives de la $7^{\mathrm{e}}$ heure de l'Amdouat, in: Ch. THIERS, (ed.), D3T 3, (Montpellier 2015), pp. 247-271.

- Roeder, G., Der Tempel von Dakke, Les temples immergés de la Nubie, (Le Caire 1930).

- Siegmann, R. et al. (ed.), Unter dem Schutz der Himmelsgöttin: Ägyptische Särge, Mumien und Masken in der Schweiz, (Zürich 2007).

- Stadler, M., Weiser und Wesir: Studien zu Vorkommen, Rolle und Wesen des Gottes Thot im ägyptischen Totenbuch, ORA (Tübingen 2009).

- Stanley, Z, B., The Title hrry-sšt3 to the End of the New Kingdom, in: JARCE 45 (2009/2010), pp. 319-348.

- Te Velde, H., Seth: God of Confusion- A Study of his Role in Egyptian Mythology and Religion (Leiden 1977). 


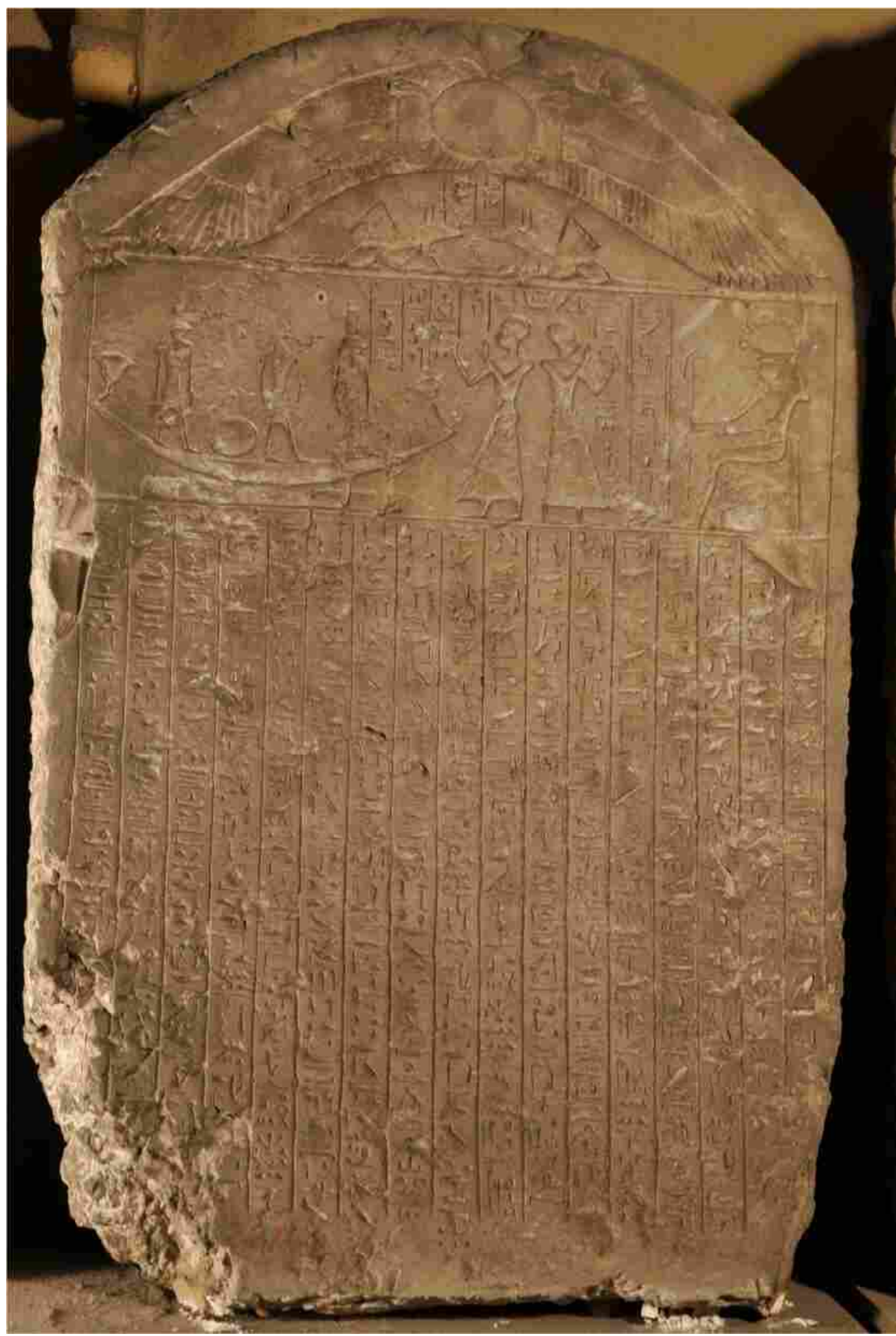

Fig. I: stela CG 22142 (C) Egyptian Museum Cairo. 

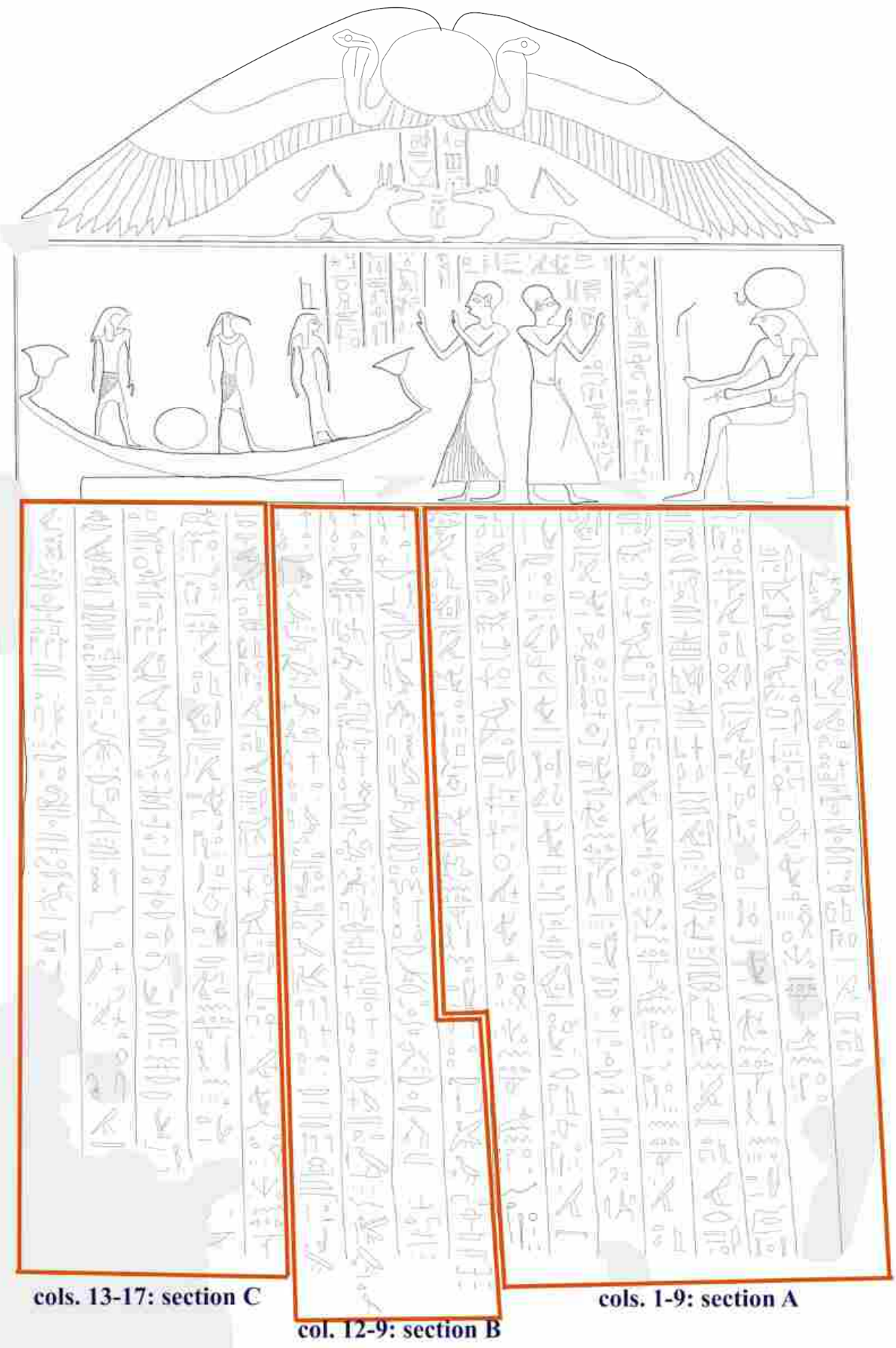

Fig. II: line drawing for the stela including the lunette, register and main text with its three sections.

- 35 - DOI: $10.36816 /$ shedet.006.02 